Михаел Антоловић

Универзитет у Новом Саду

Педагошки факултет Сомбор

antolovic.michael@gmail.com
Оригинални научни рад

примљено: 4. јул 2011

прихваћено: 1. октобар 2011

\title{
„НЕМАЧКА РЕПУБЛИКА ЈЕ НАЈДЕМОКРАТСКИЈА ДЕМОКРАТИЈА НА СВЕТУ“ - ПРИЛОГ ИСТОРИЈИ УСТАВНОГ УРЕЪЕЊА ВАЈМАРСКЕ РЕПУБЛИКЕ
}

Сажетак: У раду се на основу стенографских бележака немачке Националне скупштине у Вајмару и историографске литературе анализирају историјски услови у којима је донесен устав прве немачке републике. Посебна пажња посвећена је идејним утицајима којима су се руководили творци устава, у првом реду Хуго Пројс (Hugo Preuss), темељним уставним одредбама као и критици либерално-демократског поретка утврђеног уставом од стране политичке деснице и левице.

Кључне речи: устав, Немачка, Вајмар, револуција, либерализам, Хуго Пројс.

Вајмарски устав немачке републике заузима посебно важно место у модерној немачкој историји будући да је њиме остварена организација немачког друштва и државе на начелима идеологије либерализма истакнутим још 1848-1849. у раду немачке Националне скупштине у Франкфурту. По окончању покрета за немачко национално уједињење, ауторитарна структура новог немачког рајха онемогућавала је либерализацију политичких односа те је немачка монархија током читавог свог постојања, упркос убрзане економске и друштвене модернизације, у области политичких односа задржала одлике „бонапартистичке полудиктатуре“: неки од важних елемената државне организације попут војске, државне службе и дипломатије, остали су у искључивој надлежности цара и високих аристократских кругова мимо било какве спољне контроле од стране владе или парламента. ${ }^{1}$ Упркос захтевима немачких либерала за политичком реформом, немачки либерализам је почетком 20. века губио на снази будући да су широки слојеви немачког грађанства прихватали национализам као доминантну идеологију, док је бројно радништво највећим делом пригрлило идеје немачке социјалдемократије. Снажне социјалне,

\footnotetext{
${ }^{1}$ Hans-Ulrich Wehler, Das deutsche Kaiserreich 1871-1918, Göttingen 1975, 60-69.
} 
економске, идеолошке и политичке поделе присутне у немачком друштву додатно је заоштрио велики ратни сукоб (1914-1918) да би их демографско исцрпљивање, војни пораз и економски колапс земље довели до врхунца. Свеобухватна криза са којом се друштво империјалне Немачке суочило окончањем Првог светског рата послужила је као катализатор снажног незадовољства постојећим политичким и социјалним односима који је довео до револуционарног слома „старог режима“ и тражења нових облика друштвеног и политичког организовања. Одатле су пропаст традиционалног монархијског државног уређења са једне, те реална могућност бољшевичке револуције на другој страни, представљали историјски оквир у коме је у новембру 1918. формирана прва немачка република. Установљавајући либерални парламентарно-демократски политички систем, она је представљала раскид са немачком конзервативном традицијом и изразити вид демократизације немачког друштва. При томе, развоју либерално-демократских институција прокламованих уставом озбиљну сметњу представљала је послератна стварност Немачке обележена перманентним кризама - економском, друштвеном, политичком, које су водиле снажењу масовних идеологије политичке деснице и левице, непријатељских према идеји либерализма и грађанског друштва. „Клизећи из једне кризе у другу“ Вајмарска република је током непуне деценије и по свога постојања постепено губила подршку јавности што је, на концу, омогућило долазак на власт Националсоцијалистичке немачке радничке партије потпомогнуте конзервативним немачким елитама традиционално неповерљивим према идејама демократије и парламентаризма. Будући да је историја „нацистичког преузимања власти“ проучена са разних аспеката, намера овог рада је да укаже на историјске услове настанка прве немачке републике и основе њеног политичког система утврђене Вајмарским уставом. Ово посебно, с обзиром да је у постојећој историографској литератури на српском језику ово питање тек овлаш дотицано, најчешће у контексту сличности и разлика између устава немачке републике и уставног уређења Краљевине Срба, Хрвата и Словенаца. ${ }^{2}$

\footnotetext{
${ }^{2}$ Упореди са: Божидар Влајић, Непосредна демократија у Немачком Уставу од 1919, Српски књижевни гласник, књ. V, бр. 6, 1922, 442-448; Данило Ј. Данић, Устав Немачке републике с погледом на модерну демократију, Архив за правне и друштвене науке, књ. VII (XXIV), бр. 6, 1924, 401-418; Ljubica Kandić, Socijalno ekonomske odredbe Vidovdanskog ustava i Vajmarski ustav, Zbornik radova, Pravni fakultet, Novi Sad, god. 3, 1969, 321-337; Олга Поповић-Обрадовић, Сличности државно-правног положаја покрајина по уставном начрту Стојана Протића (1920. год.) и земаља по Вајмарском уставу (1919. год.), Анали Правног факултета у Београду, бр. 1-3, 1986, 152-161. Поново објављено у: Olga Popović-Obradović, Kakva ili kolika država?Ogledi o političkoj i društvenoj istoriji Srbije XIX-XXI veka, Beograd 2008, 357-368. Сумаран поглед на развој уставног питања у Немачкој дао је Слободан Јовановић у својој теорији државе. Види: Слободан Јовановић, Држава, Београд 1990, 463-480.

Литература о разним аспектима историје Вајмарске републике је изузетно обимна те упућујемо на неколико општих прегледа који пружају увид у савремено стање истражености појединих проблема: Wolfgang Benz, Ursula Büttner, Der Aufbruch in die Moderne - das 20. Jahrhundert. Weimar - die überforderte Republik 1919-1933, Stuttgart 2010; Eric D. Weitz, Weimar Germany: promise and tragedy, Princeton, New Jersey 2007; Eberhard Kolb, The Weimar Republic, New York 2005; Hagen Schulze, Weimar. Deutschland 1917-1933, München 2004; Hans Mommsen, The Rise and Fall of Weimar Democracy, Chapel Hill, London 1996; Richard Bessel, Germany After the First World War, Oxford 1993; Edgar J. Feuchtwanger, From Weimar to Hitler: Germany 1918-1933, Basingstoke 1993. У старијој литератури и даље је сачувало
} 
Ратни сукоб, који је државни и политички врх немачког рајха отпочео у циљу очувања постојећег ауторитарног поретка у земљи и остварења империјалистичких циљева немачке „светске политике“, до пароксизма је заоштрио постојеће политичке и социјалне односе суочивши Немачку у јесен 1918. са револуцијом. Уместо да трајно обезбеди Немачкој „место под сунцем“ и допринесе учвршћивању положаја немачких конзервативних елита које су усмеравале политички живот немачког рајха током претходног раздобља, дуготрајни светски сукоб је својеврсном историјском иронијом довео до дискредитације монархије, пада династије Хоенцолерна и „провале маса у политику“ које су захтевале признавање својих интереса посредством радикалне демократизације политичких односа. Очекивања која су се јавила међу широким слојевима бројног немачког радништва кретала су се у широком луку од реформе политичког система на либерално-демократским основама на једној, до захтева за потпуним револуционарним преокретом, одбацивањем свих „буржоаских“ институција и успостављањем пуне демократије у виду „државе већа“ на другој страни. У околностима обележеним изненадном капитулацијом војног врха, отказивањем дисциплине у војсци и истицањем револуционарних парола широм Немачке, грађанске странке, и саме дискредитоване колапсом система коме су пружале подршку, биле су затечене збивањима. Нашавши се у стању потпуне пасивности, оне су водећу улогу у политичком животу земље препустиле снагама политичке левице - немачкој социјалдемократији. ${ }^{3}$

Револуционарни покрет војничких и радничких већа која су почетком новембра 1918. успостављена широм Немачке те безизгледност њеног спољнополитичког положаја, навео је владу Макса Баденског да 9. новембра објави абдикацију цара Вилхелма и преда власт Фридриху Еберту, председнику највеће опозиционе странке - Социјалдемократске партије. Од далекосежне важности била је чињеница да немачка социјалдемократија од 1917. више није била јединствена социјалдемократска Већина је своје деловање ограничавала на либерализацију и демократизацију односа унутар парламентарног политичког система, Спартаков савез је за циљ имао изградњу државе већа посредством темељног револуционарног преображаја по узору на руске бољшевике док су се између ове две политичке опције, реформиста и револуционара, налазили Независни социјалисти заступајући компромисна, и често недовољно јасна, решења. За разлику од Спартаковаца, обе социјалдемократске партије, Већина и Независни, прихватале су парламентарнодемократски систем као оквир за своје политичко деловање упркос одређеним резервама Независних који су настојали да поједине револуционарне тековине буду потврђене будућим уставом. У намери да предупреди радикалније потезе

вредност класично дело Курта Зонтхајмера: Kurt Sontheimer, Antidemokratische Denken in der Weimarer Republik. Die politischen Ideen des deutschen Nationalismus zwischen 1918 und 1933, München 1962.

${ }^{3}$ Види: Helmut Neuhaus, Das Ende der Monarchie in Deutschland 1918, Historisches Jahrbuch, 111, 1991, 102-136; Sönke Neitzel, Weltkrieg und Revolution 1914-1918/19, Berlin 2008, 147-166. О ратним циљевима Немачке види: Fritz Fischer, Griff nach der Weltmacht. Die Kriegsziele des kaiserlichen Deutschland 1914-1918, Düsseldorf 1964. 
Спартаковаца, представник Већине, Филип Шајдеман, обзнанио је укидање монархије и прогласио прву немачку републику 9. новембра 1918. године да би наредног дана била образована привремена влада - Веће народних опуномоћеника на челу са Ебертом, у коју су ушли представници Већине и Независних социјалиста. Будући да је првенствени циљ социјалистичке Већине било сазивање Народне скупштине која би одлучила о будућем државном и друштвеном урећењу Немачке, привремена влада је већ 30. новембра донела закон о изборима за Уставотворну скупштину на принципу општег и једнаког права гласа које се односило и на жене. Потврду за своју политику привремена влада добила је у другој половини децембра на првом Националном конгресу радничких и војничких већа одржаном у Берлину на коме је одлучено да се избори одрже 19. јануара наредне године. Будући да су представници социјалистичке Већине имали суверену превагу у конгресу, предлог крајње левице да систем већа представља „основу устава социјалистичке републике“ није био прихваћен. Незадовољни реформистичком политиком привремене владе Спартаковци су, променивши назив у Комунистичку партију Немачке, 5. јануара 1919. започели демонстрације у Берлину које су биле окончане тек након вишедневних борби у којима је страдало неколико стотина немачких комуниста. Супротставивши се захтеву за спровођењем комунистичке револуције, привремена влада је, ослањајући се на војни апарат и добровољачке јединице, онемогућила револуционарни преврат и приступила консолидацији крхких темеља на којима је почивао новоуспостављени либерално-демократски режим немачке републике. ${ }^{4}$

На изборима за уставотворну скупштину одржаним 19. јануара, свега неколико дана након угушења ,јануарског устанка“ немачких комуниста, Социјалдемократска партија освојила је 37,9\% гласова и 165 посланичких мандата, док је за Независне социјалисте гласало 7,6\% бирача што им је обезбедило 22 места у скупштини. Упркос томе, две социјалистичке странке нису имале већину нити су могле саме да образују владу те су започеле сарадњу са либералним странкама које ће представљати основу тзв. Вајмарске коалищије. Реч је о католичкој Партији центра која је освојила 19,7\% гласова и 91 посланички мандат и Немачкој демократској партији која је, надовезујући се на традиције предратне либералне Прогресивне странке, освојила 18,5\% и 75 посланичких места. Странка десног центра, Немачка народна партија Густава Штреземана освојила је свега 4,4\% гласа, односно 19 места у парламенту, док је конзервативна монархистичка Немачка национална народна партија на челу са Алфредом Хугенбергом, представљајући све друштвене снаге политичке деснице противне начелима либерализма и демократије, освојила 10,3\% и 44 посланичка мандата. ${ }^{5}$

\footnotetext{
4 „Verordnung über die Wahlen zur verfassunggebenden deutschen Nationalversammlung (Reichswahlgesetz). Vom 30. November 1918“, y: Handbuch der verfassunggebenden deutschen Nationalversammlung Weimar 1919. Biographische Notizen und Bilder, herausgegeben vom Bureau des Reichstags, Berlin 1919, 10-18; Андреј Митровић, Време нетрпељивих. Политичка историја великих држава Европе (1919-1939), Београд 1974, 125-160; Hans Mommsen, нав. дело, 20-50; Eberhard Kolb, нав. дело, 7-17.

${ }^{5}$ Детаљну статистику резултата избора за Уставотворну скупштину види у: „Verzeichnis der Mitglieder der verfassunggebenden Nationalversammlung nach der Parteien“, y: Handbuch der verfassunggebenden deutschen
} 
Национална скупштина састала се 6. фебруара 1919. у провинцијском Вајмару поштеђеном револуционарних немира. Поред настојања да њен рад не буде ометан сукобима у Берлину, Вајмар је изабран за место заседања Националне скупштине како би се домаћој и иностраној јавности и на симболичкој равни упутила порука да нова послератна Немачка своје постојање темељи на хуманистичкој традицији немачке културе насупрот милитаризму пораженог рајха. Да би указао на дисконтинуитет са аутократском влашћу немачке монархије, Фридрих Еберт је, на почетку заседања, означио Националну скупштину као „врховног и јединог суверена у Немачкој“. ${ }^{6}$ Први задатак који се нашао пред посланицима скупштине било је законско санкционисање новоуспостављеног стања посредством доношења новог устава. Рад на састављању устава није био праћен већим политичким ломовим и сукобљавањима будући да су политичке снаге које су учествовале у његовој изради - социјалдемократска Већина, десно крило Независних социјалиста и грађанске либералне партије, настојале што пре да озаконе републикански поредак и отклоне опасност комунистичке револуције. У том погледу, већ је Закон о привременом управљању рајхом од 10. фебруара 1919. наговестио потоња уставна решења у односу на унутрашњу организацију државе као и расподелу ингеренција између извршне и законодавне власти. ${ }^{7}$ Закон је предвиђао дводомни скупштински систем - поред рајхстага, изабраног на основу једнаког и општег права гласа, утврђено је и постојање Горњег дома - Дома држава (Staatenhaus) у коме би биле представљене појединачне немачке државе антиципирајући, на тај начин, потоњи рајхсрат. При томе, законодавна моћ рајхстага била је ограничена претходном сагласношћу Горњег дома. Закон је утврдио и да се територијалне границе немачких држава не могу мењати без њихове сагласности. Истовремено, руковођење пословима немачког рајха поверено је председнику државе кога бира Национална скупштина и који образује владу одговорну рајхстагу. $^{8}$ Иако привременог карактера, закон је утврђивањем надлежности рајхстага, председника и владе, великим делом антиципирао будуће уставно уређење немачке републике. На темељу закона, Национална скупштина је већ 11. фебруара за првог председника републике изабрала Фридриха Еберта док је састављање владе поверила Филипу Шајдеману. Прву владу немачке републике образовали су представници социјалистичке Већине, Католичког центра и Немачке демократске партије чиме је створена тзв. Вајмарска коалииија. Осим што је уживала највећу подршку бирачког тела, она је поседовала историјски и револуционарни легитимитет за управљање државом будући да су се странке заступљене у коалицији још током вилхелминског раздобља залагале за демократизацију политичких односа у немачком рајху да би заједничким иступом у

Nationalversammlung Weimar 1919. Biographische Notizen und Bilder, 114-119; Eberhard Кolb, нав. дело, 224; О водећим политичким странкама у Вајмарској републици види: Hagen Schulze, нав. дело, 71-86.

${ }^{6}$ Verhandlungen der verfassunggebenden deutschen Nationalversammlung, Band 326, Berlin 1920, 6. Februar 1919, 1.

${ }^{7}$ „Gesetz über die vorläufige Reichsgewalt. Vom 10. Februar 1919“, y: Handbuch der verfassunggebenden deutschen Nationalversammlung Weimar 1919. Biographische Notizen und Bilder, 5-9.

${ }^{8}$ Исто, 7. 
рајхстагу 1917. затражили увођење парламентарног поретка. ${ }^{9}$ Доношењем Закона о привременом управљању рајхом и избором Еберта за председника, Национална скупштина је законски санкционисала тековине „новембарске револуције“ успостављање републиканског облика власти на темељу политичког либерализма. Револуционарни нереди усмерени ка продужетку револуције и успостављању државе већа који су током наредних месеци потресали Минхен, Лајпциг, Хамбург, Бремен, Берлин и Рајнску област, будући да су представљали претњу по новоуспостављени политички поредак били су угушени војном силом коју је влада употребила против револуционара. ${ }^{10}$

Након избора председника и формирања владе, Национална скупштина је приступила разматрању уставних предлога како би у што краћем периоду озваничила раскид са ауторитарним наслеђем немачке монархије начинивши, истовремено, и брану у односу на захтеве комунистичке левице за продужењем револуције и успостављањем државе већа. У том циљу, привремена влада је још средином новембра 1918. израду уставног нацрта поверила Хугу Пројсу, угледном професору и стручњаку за уставно-правна питања, и именовала га за државног секретара у Министарству унутрашњих послова. Пројс је своја схватања у погледу на државу и право формирао у традицијама 19-товековног немачког либерализма. Представљајући свој нацрт устава, он је устврдио да је његова водећа мисао садржана у чињеници да је немачки народ „први пут у историји остварио темељни принцип да државна власт почива на народу“. ${ }^{11}$ Одатле је Пројсова превасходна намера била да посредством потпуног парламентарног система отклони ауторитарне елементе у државном уређењу Пруске које је она задржала током постојања немачког рајха, одређујући великим делом карактер читаве савезне државе. ${ }^{12}$ Осим либералних схватања Пројса и његових сарадника, на карактер устава велик утицај имали су и ставови председника САД Вилсона Вудроа који је још уочи потписивања примирја обавестио вођство немачког рајха да демократизација и успостављање

\footnotetext{
${ }^{9}$ Fritz Fischer, нав. дело, 334-339; Eberhard Kolb, нав. дело, 18; Hagen Schulze, нав. дело, 71-72.

${ }^{10}$ Michael Kotulla, Deutsche Verfassungsgeschichte. Vom Alten Reich bis Weimar (1495-1934), Berlin, Heidelberg 2008, 583-584.

${ }^{11}$ Verhandlungen der verfassunggebenden Deutschen Nationalversammlung. Stenographische Berichte, Berlin 1920, Band 326, 24. Februar 1919, 285.

${ }^{12}$ Хуго Пројс (Hugo Preuss, 1860-1925), рођен је у Берлину у имућној породици јеврејских предузетника. Након студија права, историје и филозофије, хабилитирао је на Правном факултету у Берлину. Упркос признања које је уживао у стручним круговима, као Јеврејин и публициста демократских и либералних погледа није могао да буде биран за професора на берлинском Правном факултету, већ је тек 1906. изабран за професора уставног права на Високој трговачкој школи у Берлину. У својим публицистичким списима залагао се за либерализацију политичких односа у немачком рајху полажући наде у личност цара Фридриха III (1888). Неопходност политичке реформе изложио је по избијању светског рата у делу Немачки народ и политика (Das deutsche Volk und die Politik, 1915). Као државни секретар у Министарству унутрашњих послова он је сачинио нацрт будућег устава који је изложио Националној скупштини у Вајмару. У име Немачке демократске партије обављао је дужност министра унутрашњих послова у влади Филипа Шајдемана (фебруар-јун 1919). Након оставке владе 20. јуна 1919. у знак протеста због Версајског мировног уговора, Пројс је током последњих година живота учестовао у раду пруског ландтага. Види: Manfred Friedrich, „Hugo Preuss“, у: Neue Deutsche Biographie, Band 20 (2001), 708-710.
} 
уставног поретка представљају предуслове за постизање мировног споразума. У том смислу сасвим је оправдана тврдња Хагена Шулцеа да је Вајмарски устав био не само резултат захтева за либерализацијом политичких односа у Немачкој већ и „плод пораза у рату““. ${ }^{13}$

Под Пројсовим руководством, комисија за израду устава, у којој је суделовао и Макс Вебер, сачинила је први уставни нацрт већ почетком јануара 1919. године. ${ }^{14}$ Надовезујући се на немачку либералну традицију 19. века - у првом реду, пруског реформатора барона Штајна те либерале окупљене у Франкфуртској скупштини током револуције 1848/49, Пројс је полазио од републиканског облика владавине и демократије као темеља новог уставног уређења. При томе, он није разматрао питање основних људских права већ је у уставном предлогу тежиште ставио на унутрашње уређење земље. У том смислу, нацрт је предвиђао централизацију немачког рајха посредством укидања ранијих савезних држава (Länder) и организовања 16 нових територијалних целина сведених на ниво административних јединица уједињених унутар граница јединствене унитарне државе. ${ }^{15}$ Немачке државе, представљене у Већу држава, привлачило је првенствено питање односа надлежности централне владе према ингеренцијама појединачних држава. Одатле је, услед противљења немачких држава оваквом уставном предлогу, Пројс био принуђен да сачини нови нацрт, на шта га је приморавао и тежак спољнополитички положај у коме се налазила Немачка. У истом правцу деловао је и председник Еберт који је настојао да предстојеће преговоре о миру води влада заснована на новом уставу те се рад на изради устава одвијао у сенци мировне конференције у Паризу. Пројсова намера да практично поништи државност немачких држава, укључујући и Пруску као највећу међу њима, није била остварива у ситуацији када је положај владе и даље био угрожен устанцима и опасношћу од револуционарног преврата. Поред остатака царске војске и новообразованих добровољачких јединица - фрајкорпса који нису били довољно поуздани, једина снага на коју се влада могла ослонити током прве половине 1919. како би осигурала свој положај био је полицијски и државни апарат Пруске. Стога, планирана „атомизација“ Пруске није била изводљива те је извршена модификиција Пројсовог нацрта тиме што су му додате одредбе о темељним грађанским правима док је предвиђена територијална реорганизација немачких држава остављена за неко будуће време. У измењеном виду, предлог устава објављен је 20. фебруара и упућен Националној скупштини на разматрање. Како је она била усредсређена на проблеме везане за потписивање мировног уговора, рад на усаглашавању ставова око уставних питања одвијао се највећим делом унутар скупштинског Уставног одбора, који је бројао 28 чланова, и није изазивао значајније полемике. Обе социјалистичке партије приступале су уставном питању на формалистички начин губећи из вида да уставна решења детерминишу однос политичке моћи. Ово првенствено будући да је

\footnotetext{
${ }^{13}$ Hagen Schulze, нав. дело, 86-87.

${ }^{14}$ Види Веберове чланке - „Будући државни облик Немачке“ и „Председник Рајха“ у: Maks Veber, Politički spisi, Beograd 2006, 384-414, 426-429.

${ }^{15}$ Verhandlungen der verfassunggebenden deutschen Nationalversammlung, Band 326, Berlin 1920, 24. Februar 1919, 284-292.
} 
немачка социјалдемократија традиционално тежиште својих разматрања посвећивала социјалним односима и друштвеном уређењу а не државноправним питањима. Са друге стране, партије политичке деснице - Немачка национална народна партија и Немачка народна партија, прихватиле су проглашење републике као нужно зло и политичку неминовност залажући се за уставну и парламентарну монархију. У таквим околностима, највећи утицај на коначну физиономију и садржај устава дали су немачки либерали. Поред Пројса, међу њима су била и нека од најугледнијих имена немачке науке попут Макса Вебера, Роберта Редслоба, Валтера Јелинека и Фридриха Мајнекеа који су из рационалних разлога, као нужност опстанка државе, прихватили успостављање републике (Vernunftrepublikaner). ${ }^{16}$ Национална скупштина је, у међувремену, преузела на себе прерогативе законодавног тела и донела одлуку о привременом формирању војске и продужила важење старих законских одредби које нису биле у супротности са новоуспостављеним правним поретком. Након потписивања мировног уговора у Версају 28. јуна 1919. и његове ратификације од стране Националне скупштине 16. јула, приступило се усвајању устава. На седници одржаној последњег дана јула 1919. Национална скупштина усвојила је устав са већином од 262 гласа док је против било 75 посланика. Председник Еберт потписао је текст устава 11. августа и он је ступио на снагу 14 . августа, даном објављивања у службеном листу. ${ }^{17}$

Вајмарски устав састоји се из два дела у којима је уставна материја изложена у 181 члану. Први део посвећен је устројству и задацима немачког рајха док су у другом делу побројана основна права и дужности немачких грађана. Карактеристично је да је устав као темељни принцип прокламовао идеју народног суверенитета означивши народ као носиоца државне власти. У краткој преамбули устава изричито је речено да је „немачки народ дао себи устав“ док је у чл. 1 утврђено да република представља облик државне власти немачког рајха у којој власт проистиче из народа. ${ }^{18}$

Прво поглавље устава (чл. 1-19) посвећено је унутрашњој државно-правној организацији немачког рајха који је дефинисан као савезна држава састављена од појединих немачких земаља (Länder). При томе, остављена је могућност прикључења других покрајина на основу права народа на самоопредељење (чл. 2) упркос томе што је Мировни уговор изричито забрањивао уједињење Немачке и Аустрије. ${ }^{19}$ Ово првенствено стога што у тренутку доношења устава још увек није била утврђена коначна припадност територија у северном Шлезвигу, источној и западној Пруској, Горњој Шлезији и Сарској области као и раширеног уверења у

\footnotetext{
${ }^{16}$ Hans Mommsen, The rise and fall of Weimar Democracy, The University of North Carolina Press, 1996, 51-52; Peter Stirk, Hugo Preuss, German political thought and the Weimar constitution, History of political thought, Vol. 23, No. 3, 2002, 497-516; Waldemar Besson, Friedrich Meinecke und die Weimarer Republik. Zum Verhältnis von Geschichtsschreibung und Politik, Vierteljahrshefte für Zeitgeschichte, 7, 1959, 113-129.

${ }^{17}$ Michael Kotulla, нав. дело, 587-588.

${ }^{18}$ У раду смо користили текст устава објављен у службеном листу немачког рајха: Die Verfassung des Deutschen Reichs, Reichsgesetzblatt, Nr. 152, Jg. 1919.

${ }^{19}$ Члан 80. Мировног уговора у Версају забранио је аншлус - припајање Аустрије немачком рајху.
} 
немачкој јавности да ће принцип самоопредељења народа бити доследно примењен и на немачке земље. ${ }^{20}$ Према томе, у тренутку доношења устава, немачки рајх се састојао од укупно 24 јединице да би докраја 1928, услед територијалне реорганизације, њихов број био сведен на 17 земаља. ${ }^{21}$ Будући да чланице немачког рајха нису располагале суверенитетом, он је, по суду Карла Шмита, представљао „савезну државу без савезног темеља“. Савезна држава имала је своје правно утемељење у одлуци Националне скупштине а не на одлукама њених чланица да ступе у државни савез. Устав је прописивао искључиво суверенитет немачког рајха обавезујући за све земље. На тај начин је и положај највећег конститутивног дела рајха - Пруске, која је сачињавала чак $3 / 5$ савезне државе, формално-правно изједначен са осталим немачким земљама. ${ }^{22}$ Уставом нису биле прописане гаранције за очување државноправних посебности појединих немачких земаља чиме је остављена могућност за потоње унутрашње преуређење рајха док је, истовремено, чл. 17 обавезивао сваку земљу да своје уређење усклади са републиканским обликом немачког рајха, обезбеди опште право гласа и устроји парламентарни облик власти. На тај начин, устав је настојао да онемогући успостављање власти у појединим немачким земљама на монархистичким темељима или, пак, на принципу совјетске републике већа. За разлику од устава немачког царства из 1871. који је државама-чланицама остављао могућност да саме уреде облик државне власти, Вајмарски устав је посредством „клаузуле о хомогености“ прописао да устави земаља морају бити усклађени са његовим темељним принципима те су, закључно са 1923, све земље донеле нове уставе. ${ }^{23}$

Уставом је било одређено да се у искључивој надлежности централних власти налазе питања спољних послова, држављанства, војске, штампања новца, царина и пошта (чл. 6). Истовремено, законодавна овлашћења рајха односила су се и на области грађанског, кривичног и процесног права, путне исправе, штампу, удружења и скупове, здравство, саобраћај и социјалну политику (чл. 7), а у случају потребе и на социјално старање и заштиту јавне безбедности и државног поретка (чл. 9). У домен рајха уврштено је и уређење основних принципа у области верских организација, школства, чиновништва и јавних служби, сахрањивања, земљишног права и опорезивања (чл. 10). Надлежност у преосталим областима устав је препуштао ингеренцији савезних држава. Важна је чињеница да је рајх, задржавши за себе у потпуности надлежности у области финансијске политике као и увођењем јединственог пореског система, укинуо финансијску самосталност немачких земаља. Спровођење закона рајха било је, према уставу, у надлежности појединих земаља

\footnotetext{
${ }^{20}$ Упореди са: Maks Veber, нав. дело, 388-389, 395.

${ }^{21}$ Након територијалне реорганизације, од краја 1928. немачки рајх сачињавали су: Пруска, Баварска, Саксонија, Виртемберг, Баден, Хесен, Тирингија, Мекленбург-Шверин, Мекленбург-Штрелиц, Олденбург, Брауншвајг, Липе, Шаумбург-Липе, Анхалт, Хамбург, Либек и Бремен. Види: Michael Kotulla, нав. дело, 589.

${ }^{22}$ Иако је изгубила свој посебан положај који је имала раздобљу 1871-1918., Пруска је и у вајмарској Немачкој представљала нарочито важан чинилац политичког живота као „фактички хегемонијална сила““. Исто, 589-590.

${ }^{23}$ Исто, 590.
} 
(чл. 14.) при чему је централна власт задржала за себе право контроле. У случају уочених неправилности у спровођењу државних закона земаљске власти биле су у обавези да по налогу централних власти неправилности отклоне (чл. 15).

Уставна материја посвећена органима немачког рајха изложена је у другом, трећем и четвртом поглављу Вајмарског устава. У њима су утврђени органи рајха председник, влада, рајхстаг, рајхсрат, привредно веће рајха, Уставни суд, и дефинисана њихова овлашћења. Сходно одредбама устава, председник рајха јесте врховни државни поглавар. Имајући у виду начин избора, трајање мандата и распон овлашћења председника, уочљива је сличност са положајем некадашњег цара у политичком систему империјалне Немачке. Одатле је функција председника већ од савременика била означена као једна врста „замене за цара“ (Ersatzkaiser). Посебан положај председника немачког рајха проистицао је из чињеница да је устав прописивао да њега бира „читав немачки народ“ а за председника може да буде изабран „сваки Немац који је напунио 35 година живота“ (чл. 41). Трајање председничког мандата било је ограничено на седам година уз могућност поновног избора (чл. 43). Будући да је биран на непосредним изборима, легитимитет председника рајха изједначен је са легитимитетом рајхстага. ${ }^{24}$ Овлашћења председника била су веома широка и подразумевала су заступање рајха, именовање и отпуштање чиновника рајха, врховну команду над војском, именовање и смењивање канцелара и министара те право помиловања (чл. 45-49). Поред тога, председник је имао право да распусти рајхстаг али само једном по истој основи (чл. 25) те да нареди употребу „оружане силе“ против чланице рајха која „не испуњава обавезујуће дужности које проистичу из устава и закона рајха““ (чл. 48). ${ }^{25}$ У истом члану устав је прописивао да председник рајха у случају угрожавања јавне безбедности и поретка, може преузети „неопходне мере“ и „по потреби да поступи уз помоћ оружане силе“ као и да привремено, у целини или делимично, обустави важење основних грађанских права попут личне слободе, неповредивости стана, тајности писма, поште, телеграфа и телефона, слободе мишљења и штампе, слободе окупљања, неповредивост својине (чл. 48, став 2). Имајући и виду овако широка овлашћења која је устав давао председнику снабдевајући га „диктаторском влашћу“ ради очувања уставом прописаног поретка, несумњиво је да су и сами творци устава гајили неповерење у односу на карактер парламентарног система владавине. ${ }^{26}$

\footnotetext{
${ }^{24}$ Први председник Вајмарске републике, Фридрих Еберт, није био биран на изборима већ је, у светлу нестабилних политичких прилика, рајхстаг продужио његов мандат до 30. јуна 1925. године. Како је Еберт преминуо у фебруару 1925, на изборима одржаним у априлу исте године за председника је изабран фелдмаршал Паул фон Хинденбург, Michael Kotulla, нав. дело, 592; Hans Mommsen, нав. дело, 234-237.

${ }^{25}$ Ову могућност у три наврата је искористио председник Еберт - два пута против радикалних лево оријентисаних влада у седам малих држава у Тирингији у првој половини 1920. и у октобру 1923. против комунистичке земаљске владе у Саксонији. Последњи пут је „егзекутива рајха“ била употребљена за обарање пруске владе у лето 1932. са образложењем да се није супротставила комунистичким изгредима. 26 Томе у прилог сведочи и оновремени суд Фридриха Мајнекеа који је у широким овлашћењима додељених уставом председнику рајха видео „кротитеља демократског-ирационалних снага“, Michael Kotulla, нав. дело, 593. Види: Friedrich Meinecke, „Bemerkungen zum Entwurf des Reichsverfassung“, у: Friedrich Meinecke, Politische Schriften und Reden, herausgegeben von Georg Kotowski, Darmstadt 1968, 299-312.
} 
Владу рајха према уставу чине канцелар и министри (чл. 52). На предлог канцелара, председник рајха именује, односно разрешава, поједине министре (чл. 53) док је влада у целини одговорна рајхстагу (чл. 54). Имајући у виду нестабилност политичких прилика, политички живот Вајмарске републике био је обележен краткотрајним владама. Именовање канцелара било је у надлежности председника рајха који је на ту функцију предлагао кандидата парламентарне већине. У случају да у рајхстагу није било могуће успоставити неопходну већину или је рајхстаг био распуштен, председник је имао право да именује канцелара и владу без сагласности парламента. Такав је био случај током година кризе републике од марта 1930. до Хитлеровог ступања на власт у јануару 1933. године. ${ }^{27}$

Рајхстаг је заузимао средишње место у политичком систему Вајмарске републике. Рајхстаг чине посланици који су „представници читавог народа“ и у своме деловању „подложни су само својој савести“ (чл. 21). Посланике бирају сви мушкарци и жене старији од двадесет година на основу општег и једнаког бирачког права посредством тајног и непосредног гласања (чл. 22). ${ }^{28}$ Чисти пропорционални систем избора посланика за рајхстаг настојао је да онемогући изборне манипулације карактеристичне за парламентарне изборе у немачком царству али је, истовремено, имао за последицу заступљеност мноштва малих партија у рајхстагу што је, у великој мери, отежавало његов рад. Осим тога што је располагао искључивом законодавном влашћу, рајхстаг је имао право законодавне иницијативе (чл. 68), искључиво право утврђивања државног буџета (чл. 85-87) док су се његове надлежности односиле и на објаву рата и закључење мира те ратификацију међудржавних уговора (чл. 45). У надлежности рајхстага било је и да „тужи председника, канцелара и министре државном кривичном суду немачког рајха“ у случају да су они извршили кривичну повреду устава или државних закона (чл. 59). Према томе, кривична одговорност носилаца извршне власти представљала је значајну новину у односу на уставна решења у Немачком царству. Законодавна власт била је делом ограничена чињеницом да је проглашење закона било у ингеренцији председника републике који је могао, у случају неслагања са законским предлогом, да року од месец дана распише референдум на коме би се бирачи изјаснили о предложеном закону. Ипак, током постојања Вајмарске републике овај институт није кориштен. Са друге стране, сходно начелима парламентаризма, устав је прописао одговорност канцелара и владе рајхстагу. Променљиви однос снага у рајхстагу и одсуство стабилне парламентарне већине условили су често смену влада

\footnotetext{
${ }^{27}$ Eberhard Kolb, нав. дело, 116-135.

${ }^{28}$ Измене и допуне изборног закона које се уследиле 1920. и 1924. утврдиле су 35 изборних јединица у којима су политичке странке постављале своје бирачке листе. Број посланичких места у рајхстагу није био утврђен, већ је зависио од броја гласача који су изашли на биралишта при чему је 60.000 освојених гласова у једној изборној јединици доносило странци један посланички мандат. Одатле је, у зависности од излазности на биралишта, број посланика заступљених у рајхстагу флуктуирао од 466 након избора у јуну 1920. и чак 608 после избора у јулу 1932. године. Michael Kotulla, нав. дело, 593.
} 
те се са правом може говорити о трајној кризи парламентаризма као обележју политичког живота Вајмарске републике. ${ }^{29}$

По узору на бундесрат током раздобља царства, устав је утврдио постојање Горњег дома - Pajхсрата као тела у коме су „представљене немачке земље приликом доношења закона и управљања рајхом“" (чл. 60). Број представника са којима је свака поједина земља била заступљена у рајхсрату зависио је од броја становника, при чему је устав прописивао да свакој држави припада барем једно место у овом телу. Како би се онемогућила бројчана превласт најмногољудније Пруске у којој је према попису из 1925. живело чак 38 милиона грађана док је у свим осталим немачким земљама заједно живело само 24 милиона грађана, устав је утврђивао да ниједна земља не може да има више од $2 / 5$ представника у рајхсрату (чл. 61). ${ }^{30}$ Ова одредба била је од посебне важности имајући у виду чињеницу да чланови рајхсрата нису бирани на изборима већ су били делегирани чланови својих земаљских влада. Изузетак је, опет, представљала Пруска у којој су половину њених гласова чинили представници пруских провинција (чл. 63). Председавање рајхсратом припадало је представнику владе рајха који је руководио и радом његових одбора, при чему су чланови владе имали право али и обавезу да учествују у његовом раду (чл. 65). Рајхсрат је располагао правом вета на законске предлоге рајхстага и могао је да их врати на поновно разматрање. Уколико би предлог закона у поновљеном гласању добио двотрећинску подршку рајхстага, председник републике имао је могућност да закон објави или да, пак, распише референдум (чл. 74).

У циљу рада на законском уређивању социјалних и привредних питања, устав је предвидео успостављање Привредног већа рајха. Замишљено као представништво привредних институција посредством кога би се оснажио утицај радништва на токове економске политике, ово тело требало је да даје стручно мишљење о законским предлозима који су се тицали економских и социјалних односа док је, истовремено, и само располагало правом законодавне иницијативе (чл. 165). У политичком животу, ово тело практично никада није заживело. ${ }^{31}$ Коначно, уставом је било предвиђено оснивање Уставног суда за немачки рајх на основу посебног закона (чл. 108), а до његовог доношења установљен је привремени Уставни суд од седам чланова од којих је четири предложио рајхстаг а три Врховни суд (чл. 172). Уставни суд основан је средином 1921. у Лајпцигу и бавио се решавањем поступака везаних за уставно право, у првом реду мерама централних власти према појединим немачким земљама. Устав је утврђивао и елементе непосредне демократије у виду плебисцита приликом територијалних измена и

\footnotetext{
${ }^{29}$ У раздобљу 1919-1933. формирано је чак 14 влада. Последњу, 15. по реду, владу републике образовао је Адолф Хитлер 30. јануара 1933. године.

30 У случају доследне примене пропорционалне заступљености немачких земаља у рајхсрату, сама Пруска би у њему са своја 54 гласа била у апсолутној већини у односу на 41 глас свих преосталих немачких земаља заједно. Одатле је у раздобљу 1926-1928. рајхсрат бројао укупно 68 чланова од којих је Пруској припадало 27, Michael Kotulla, нав. дело, 593.

31 О Привредном већу рајха види: Gerhard A. Ritter, Die Entstehung des Räteartikels der Weimarer Reichsverfassung, Historische Zeitschrift, 258, 1994, 73-112.
} 
стварања нових земаља (чл. 18), избора председника републике (чл. 41) те његове смене пре истека седмогодишњег мандата (чл. 43). ${ }^{32}$ Коначно, устав је прописао и могућност грађанске иницијативе посредством подношења законских предлога уколико се обезбеди подршка 1/10 бирачког тела. У случају да рајхстаг одбаци поднети законски предлог, о његовој судбини одлучивало би се на референдуму (чл. $73-76) .^{33}$

У другом делу устава побројана су „основна грађанска права и дужности Немаца“ (чл. 109-165). Полазећи од равноправности свих грађана пред законом, устав је учинио крај привилегованом положају племства укинувши повластице на основу рођења или припадности одређеном сталежу (чл. 109). Истовремено, уставом је била прописана равноправност мушкараца и жена (чл. 109, 119). Поред класичних либералних вредности - правне једнакости, слободе и неповредивости личности, слободе говора, штампе, удруживања, те тајности писма, уставом су били нормирани и принципи на којима треба да се одвија друштвени живот (Gemeinschaftsleben), у првом реду наглашена је важност породице и нормиране обавезе родитеља, васпитање деце те рад друштвених организација и удружења. Посебна поглавља устава била су посвећена уређењу питања везаних за религију и верска удружења (чл. 135-141), образовање и школу (чл. 142-150) и привредни живот (чл. 151-165). Устав је гарантовао слободу вероисповести, несметан приступ државним и чиновничким функцијама без обзира на конфесионалну припадност, као и приватност личних религијских уверења. Утврђујући непостојање службене државне цркве, устав је омогућио слободно деловање верских организација као корпорација јавног права у законом прописаним оквирима. Устав је, даље, прописивао слободу научног и уметничког стваралаштва и њиховог подучавања којима држава „обезбеђује заштиту и учествује у њиховом неговању“. Истовремено, утврђено је постојање обавезног основношколског образовања у трајању од најмање осам година, као и обавеза државне потпоре ученицима и студентима лошијег социјалног положаја. Устав је дефинисао да се у „свим школама мора тежити моралном образовању, државном осећању те личној и професионалној ваљаности у духу немачке народности и разумевања међу народима“, чиме су творци устава још једном нагласили своју приврженост републиканским идеалима (чл. 148). У поглављу посвећеном привредном животу, садржана је истоветна идеја у одредби да устројство привредног живота мора да одговара „принципима правичности у циљу гаранције достојанственог људског живота за све“ (чл. 151). Са овог становишта, устав је утврдио основна социјална права попут права на здраво становање, право породице на стамбено и привредно пребивалиште у складу са њеним потребама,

\footnotetext{
32 Плебисцити поводом територијалних измена организовани су само поводом поделе Горње Шлезије 1922. и издвајања Хановера из Пруске 1924. године, у оба случаја без успеха.

${ }^{33}$ На основу ове уставне могућности у три наврата организован је референдум. Иницијатива подстакнута 1926. од комуниста и социјалдемократа за плебисцитом у корист одузимања кнежевских добара стављених под секвестар 1918. доживела је неуспех као и иницијатива 1928. усмерена против изградње нове оклопне крстарице. Последњи пут ову уставну могућност искористиле су десничарске политичке странке покушавши, такође без успеха, да осујете спровођење Јанговог плана о репарацијама, 1929. године.
} 
стварања свеобухватног социјалног осигурања у циљу збрињавања последица узрокованих „старошћу, слабошћу и несрећама“ (чл. 161), право радника да радом обезбеди своје издржавање као и да „равноправно у заједници са послодавцима учествује у утврђивању услова рада и надница као и у укупном привредном развоју производних снага“" (чл. 165). У овим одредбама уочљива је интенција устава не само да, у духу либералног поимања уставности, заштити појединца од свемоћи државе, већ да се управо посредством државних институција обезбеди поштовање, првенствено, социјалних права појединаца чиме је устав приписао немачкој републици одлике социјалне државе. ${ }^{34}$ У погледу дужности грађана немачког рајха устав је прописао дужност родитеља да васпитавају децу (чл. 120), дужност преузимања додељених почасних служби (чл. 132), војну обавезу (чл. 133), обавезу плаћања пореза у складу са сопственим способностима (чл. 134), обавезност похађања школе (чл. 145), дужност земљопоседника да обрађују своје поседе (чл. $155)$ и дужност коришћења сопствених духовних и телесних снага у корист општег добра (чл. 163).

Пуних седам деценија након иступа немачких либерала у националној скупштини у Франкфурту, Вајмарски устав афирмисао је принципе либералне политичке идеологије. Имајући у виду историјски значај овог чина Едуард Давид, министар унутрашњих послова, након усвајања устава са патосом је устврдио да је немачки устав најконсеквентније спровео у дело идеју демократије, чиме је „немачка република најдемократскија демократија на свету“. ${ }^{35}$ Ипак, упркос намерама уставотвораца, политичка реалност Немачке није погодовала развоју либерално-демократских институција. Тежак међународни положај као и сложени економски, друштвени и политички проблеми са којима се суочила Вајмарска република непосредно по своме постанку, условили су слабу подршку немачких грађана новоуспостављеној држави те се веома брзо показало да она представља „републику без републиканаца“. Установљена у тренутку војног и националног пораза, немачка република и њен устав прихваћени су у широким круговима немачке јавности као нешто само по себи страно немачком духу, наметнуто од стране победничких сила у Првом светском рату. Уместо рационалног суочавања са ситуацијом проистеклом окончањем Првог светског рата, кругови политичке деснице конструисали су мит о „ударцу у леђа“ и „новембарским криминалцима“ приписавши га „мангупима без отаџбине“ - припадницима немачке социјалдемократије који су посредством револуције издали државу и признали капитулацију наводно непоражене немачке војске. Настала у круговима антирепубликанске опозиције одане династији Хоенцолерна и традицијама немачке монархије, теза о „новембарској издаји“ скована је са намером да пренебрегне реалност ратног пораза и дискредитује политичке снаге које су успоставиле републикански поредак. Ова квалификација је потом приписивана свим

\footnotetext{
${ }^{34}$ Michael Kotulla, нав. дело, 599.

${ }^{35}$ Verhandlungen der verfassunggebenden deutschen Nationalversammlung, Bd. 329, Berlin 1920, 31. Juli 1919, 2195.
} 
поборницима немачке републике и политике испуњавања одредби Версајског мировног уговора. Припадници политичке деснице су као „новембарске криминалце“ означавали водеће личности политичког живота републике попут Фридриха Еберта, Филипа Шајдемана, Матијаса Ерцбергера, Валтера Ратенауа па чак и Густава Штреземана. ${ }^{36}$ Одатле је немачка република започела своје постојање у изразито антидемократској политичкој култури непријатељској у односу на принципе либералног парламентарно-демократског уређења утврђеног уставом. Надовезујући се на идеју о „немачком посебном путу“, поборници конзервативних недемократских идеја заговарали су вредности органске заједнице насупрот модерном друштву утемељеном на слободном појединцу истичући, истовремено, супериорност немачке културе у односу на тековине декадентне, на материјализму утемељене, западноевропске цивилизације. У склопу ових идеја одбациван је и парламентаризам као неприкладан немачком „националном духу“ будући да представља формализовану владавину безимене већине. Заједно са порицањем вредности либерално-демократског политичког поретка и партијског система, одвијала се и критика Вајмарског устава са позиција политичке деснице. На другој страни, уређење које је утврдио устав било је предмет беспоштедне критике немачких комуниста који су се залагали за спровођење револуције, укидање капитализма и успостављање диктатуре пролетеријата. Док су комунисти, у духу пролетерског интернационализма, захтевали успостављање совјетске републике као истинске државе немачких радника, различите струје немачких десничара уједињавала је отворена мржња према републиканском поретку. Сматрајући Вајмарски устав неприкладан немачкој традицији, политичка десница је захтевала доношење устава који би уважавао особености немачког историјског развоја, обезбедио јединство немачког народа издељеног различитим политичким интересима и омогућио поновно снажење немачког рајха у унутрашњој и спољној политици. О расположењу националистичких и конзервативних духова сликовито сведочи став историчара Аделберта Вала који је револуционарне „идеје из 1789. год.“ сматрао узроком пропасти Немачке. Попут широког круга својих истомишљеника, Вал је истицао да настојање да „Немачка оздрави посредством увођења западноевропског (читај: француског) устава“, представља „гротескну идеју“. ${ }^{37}$

У историографији и публицистици отворено је питање нису ли управо слабости у структури политичког система утврђеног Вајмарским уставом условиле његово перманентно слабљење пред снагама крајње политичке деснице и левице које је, у време светске економске кризе, коначно довело до краха републике. На овај проблем указао је још 1928. историчар Артур Розенберг запитавши се да ли би можда демократија у Немачкој имала снажније упориште у случају да је револуција 1918/1919. била свеобухватнија и далекосежнија. Са становишта потоњег развитка,

\footnotetext{
${ }^{36}$ Види: C. Paul Vincent, A Historical Dictionary of Germany’s Weimar Republic, Westport - Connecticut, London 1997, 345-346.

${ }^{37}$ Kurt Sontheimer, нав. дело, 180-249, на овом месту 236. Упореди са: Alaster Hamilton, Fašizam $i$ intelektualci 1919-1945, Beograd 1978, 127-218.
} 
историографија након Другог светског рата прихватила је став да је социјалдемократска Већина, настојећи да онемогући радикалне друштвене и политичке промене, пропустила историјску прилику да успостави истински демократски поредак и либерализује немачко друштво. У том смислу, карактеристичан је суд савременог историчара Рајхарда Рирупа који сматра да немачка социјалдемократија није извршила разградњу ауторитарног система империјалне Немачке пропустивши тиме могућност да, у сарадњи са радничким и војничким већима, спроведе „далекосежну демократску реорганизацију политичких, друштвених и економских односа“ која би развој демократских односа учинила стабилнијим. ${ }^{38}$ Са друге стране, Волфганг Момзен указује на чињеницу да је након успостављања Вајмарске републике социјалдемократска Већина извршила стабилизацију новог политичког поретка посредством политике војних репресалија у односу на припаднике комунистичке левице. Тиме је даљи поход револуције у немачким земљама био окончан, али је он за последицу имао снажне социјалне поделе унутар немачког друштва па чак и у немачком радништву које су, у значајној мери, ослабиле друштвену основу на којима је почивала немачка република. ${ }^{39}$ Одатле, у тренуцима свеопште друштвене, економске и политичке кризе (1930-1933) одсуство општег друштвеног поверења у институције републике показало се од пресудне важности. Ово првенствено, будући да је тиме био омогућен долазак на власт ауторитарном националистичком покрету који је у првих неколико месеци владавине одстранио све елементе уређења утврђеног Вајмарским уставом и успоставио режим фашистичке диктатуре. ${ }^{40}$

\section{Извори и литература:}

Benz, Wolfgang, Ursula Büttner, Der Aufbruch in die Moderne - das 20. Jahrhundert. Weimar - die überforderte Republik 1919-1933, Stuttgart 2010.

Bessel, Richard, Germany After the First World War, Oxford 1993.

Besson, Waldemar, Friedrich Meinecke und die Weimarer Republik. Zum Verhältnis von Geschichtsschreibung und Politik, Vierteljahrshefte für Zeitgeschichte 7, München 1959, 113-129.

Влајић, Божидар, Непосредна демократија у Немачком Уставу од 1919, Српски књижевни гласник, књ. V, бр. 6, Београд 1922, 442-448.

Данић, Данило Ј., Устав Немачке републике с погледом на модерну демократију, Архив за правне и друштвене науке, књ. VII (XXIV), бр. 6, Београд 1924, 401-418.

Feuchtwanger, Edgar J., From Weimar to Hitler: Germany 1918-1933, Basingstoke 1993.

Fischer, Fritz, Griff nach der Weltmacht. Die Kriegsziele des kaiserlichen Deutschland 1914-1918, Düsseldorf, 1964.

Friedrich, Manfred, Hugo Preuss, Neue Deutsche Biographie, Band 20, München 2001, 708-710.

\footnotetext{
38 Wolfgang J. Mommsen, Die deutsche Revolution 1918-1920. Politische Revolution und soziale Protestbewegung, Geschichte und Gesellschaft, 4. Jg., H. 3, 1978, 367.

${ }^{39}$ Исто, 391.

${ }^{40}$ Детаљно у: Hans Mommsen, нав. дело, 490-544.
} 
Gesetz über die vorläufige Reichsgewalt. Vom 10. Februar 1919, Handbuch der verfassunggebenden deutschen Nationalversammlung Weimar 1919. Biographische Notizen und Bilder, (herausgegeben vom Bureau des Reichstags), Berlin 1919, 5-9.

Hamilton, Alaster, Fašizam i intelektualci 1919-1945, Beograd 1978.

Јовановић, Слободан, Држава, Београд 1990.

Kandić, Ljubica, Socijalno ekonomske odredbe Vidovdanskog ustava i Vajmarski ustav, Zbornik radova 3, Pravni fakultet, Novi Sad, 1969, 321-337.

Kolb, Eberhard, The Weimar Republic, New York 2005.

Kotulla, Michael, Deutsche Verfassungsgeschichte. Vom Alten Reich bis Weimar (1495-1934), Berlin-Heidelberg 2008.

Meinecke, Friedrich, Bemerkungen zum Entwurf des Reichsverfassung, Friedrich Meinecke, Politische Schriften und Reden, (herausgegeben von Georg Kotowski), Darmstadt 1968, 299-312.

Митровић, Андреј, Време нетрпељивих. Политичка историја великих држава Европе (19191939), Београд 1974.

Mommsen, Hans, The Rise and Fall of Weimar Democracy, Chapel Hill-London 1996.

Mommsen, Wolfgang J., Die deutsche Revolution 1918-1920. Politische Revolution und soziale Protestbewegung, Geschichte und Gesellschaft Jg.4, H. 3, Berlin 1978, 362-391.

Neitzel, Sönke, Weltkrieg und Revolution 1914-1918/19, Berlin 2008.

Neuhaus, Helmut, Das Ende der Monarchie in Deutschland 1918, Historisches Jahrbuch 111, Freiburg-München 1991, 102-136.

Поповић-Обрадовић, Олга, Сличности државно-правног положаја покрајина по уставном наирту Стојана Протића (1920. год.) и земаља по Вајмарском уставу (1919. год.), Анали Правног факултета у Београду 1-3, Београд 1986, 152-161.

Popović-Obradović, Olga, Kakva ili kolika država?Ogledi o političkoj i društvenoj istoriji Srbije XIX-XXI veka, Beograd 2008.

Ritter, Gerhard A., Die Entstehung des Räteartikels der Weimarer Reichsverfassung, Historische Zeitschrift 258, München 1994, 73-112.

Schulze, Hagen, Weimar. Deutschland 1917-1933, München 2004.

Sontheimer, Kurt, Antidemokratische Denken in der Weimarer Republik. Die politischen Ideen des deutschen Nationalismus zwischen 1918 und 1933, München 1962.

Stirk, Peter, Hugo Preuss, German political thought and the Weimar constitution, History of political thought, Vol. 23, No. 3, Exeter-Devon 2002, 497-516.

Veber, Maks, Politički spisi, Beograd 2006.

Verhandlungen der verfassunggebenden deutschen Nationalversammlung, Band 326, Berlin 1920.

Die Verfassung des Deutschen Reichs, Reichsgesetzblatt, Nr. 152, Berlin 1919.

Verordnung über die Wahlen zur verfassunggebenden deutschen Nationalversammlung (Reichswahlgesetz). Vom 30. November 1918, Handbuch der verfassunggebenden deutschen Nationalversammlung Weimar 1919. Biographische Notizen und Bilder (herausgegeben vom Bureau des Reichstags), Berlin 1919, 10-18.

Vincent, C. Paul, A Historical Dictionary of Germany's Weimar Republic, Westport - Connecticut, London 1997.

Wehler, Hans-Ulrich, Das deutsche Kaiserreich 1871-1918, Göttingen 1975.

Weitz, Eric D., Weimar Germany: promise and tragedy, Princeton-New Jersey 2007. 


\title{
“GERMAN REPUBLIC IS THE MOST DEMOCRATIC DEMOCRACY IN THE WORLD” - CONTRIBUTION TO THE HISTORY OF THE CONSTITUTIONAL ORDER OF WEIMAR REPUBLIC
}

\begin{abstract}
Summary
On the basis of the shorthand notes of the German National Assembly in Weimar, and historical literature, the paper analyzed historical conditions in which the Constitution of the first German Republic was brought. A special attention was paid to the ideological influences which guided the creators of the Constitution, primarily Hugo Preuss, to the basic constitutional provisions, as well as to the criticism of the liberal-democratic order established through the Constitution by the political right and left wings.
\end{abstract}

Keywords: Constitution, Germany, Weimar, revolution, liberalism, Hugo Preuss. 